\title{
Clinical applications of immunofixation: a more sensitive technique for the detection of Bence Jones protein
}

\author{
JT WHICHER, L HAWKINS, AND J HIGGINSON \\ From the Department of Chemical Pathology, Bristol Royal Infirmary, Bristol BS2 8HW, UK
}

SUMMARY Immunofixation in agarose gel has been compared with agarose electrophoresis for the detection of Bence Jones protein in urine. The technique has a sensitivity between five and 10 times greater than electrophoresis and allows the identification of multiple Bence Jones proteins and Bence Jones proteins with fast mobility in the presence of other urinary proteins. In four out of 12 patients studied, Bence Jones protein was undetectable by electrophoresis of 300 times concentrated urine but was clearly identified by immunofixation.

The detection of Bence Jones protein in urine is of considerable importance in the diagnosis of immunocytoma. Not only do some $20 \%$ of patients with myeloma have Bence Jones protein in the urine with no detectable paraprotein in the serum, ${ }^{1}$ but the presence of urinary Bence Jones protein is probably one of the most important criteria for deciding whether a serum paraprotein is of malignant origin.

It is essential before proceeding to immunoelectrophoresis to show first that the free light chains are homogeneous on electrophoresis and thus monoclonal. ${ }^{2}$ The reason for this is that immunoelectrophoresis with conventional light chain antisera or free light chain antisera may give misleading results as it frequently produces precipitin arcs for both kappa and lambda light chains in normal and pathological urines. More disturbing is the not uncommon finding of an arc of kappa light chains alone in the presence of polyclonal light chain excretion. This is usually because urine normally contains twice as much kappa as lambda light chain and because kappa antisera are often of higher titre than lambda antisera.

In immunofixation proteins are fixed in situ by specific antisera applied to the electrophoretic separation. It is thus possible to assess the heterogeneity of urinary light chains of each type with a high degree of resolution. Owing to the enhancement of protein-staining achieved by precipitating proteins with antibody in the electrophoretic medium immunofixation is considerably more sensitive in detecting monoclonal light chains than electrophor-

Received for publication 10 October 1979 esis. Moreover, Bence Jones proteins of fast mobility or present as multiple bands can be clearly identified in the presence of heavy proteinuria of glomerular or tubular origin.

\section{Material and methods}

URINE CONCENTRATION

The urines from 12 patients with myeloma were filtered through a $0.22 \mu \mathrm{m}$ filter (Millipore, London, UK) and $10 \mathrm{ml}$ of each was concentrated to $0.03 \mathrm{ml}$ $(300 \times)$ using a membrane thimble (Sartorius, Göttingen, Germany) as described by Hobbs. ${ }^{2}$ A series of dilutions was made to test the sensitivity of the different methods of detecting Bence Jones protein. The concentrated urines were diluted with $0 \cdot 15 \mathrm{M}$ sodium chloride solution to give a range of dilutions from $1 / 5$ to $1 / 200$.

ELECTROPHORESIS AND IMMUNOFIXATION

Electrophoresis and immunofixation were carried out as described in the previous paper. Samples were applied to the gel for 3 minutes. Antisera to kappa and lambda light chains were obtained from Dakopatts, Copenhagen, Denmark.

\section{Results}

Twelve urines were examined to ascertain the sensitivity of detection of Bence Jones protein by electrophoresis and immunofixation. The results are shown in the Table. In every case, Bence Jones protein was detectable by immunofixation at a considerably higher dilution of the concentrated urine than by electrophoresis. In four patients, 
Comparison of sensitivity of electrophoresis and immunofixation for the detection of Bence Jones protein in 12 patients with myeloma

\begin{tabular}{lll}
\hline Patient & \multicolumn{2}{c}{$\begin{array}{l}\text { Maximal dilution of urine concentrate at which Bence } \\
\text { Jones protein was visible }\end{array}$} \\
\cline { 2 - 3 } & Immunofixation & Electrophoresis \\
\hline 1 & 500 & 200 \\
2 & 50 & 30 \\
3 & 5 & Undiluted \\
4 & 30 & 5 \\
5 & 500 & 50 \\
6 & 200 & 20 \\
7 & 100 & 10 \\
8 & 10 & Undiluted \\
9 & Undiluted & Invisible Undiluted \\
10 & & \\
11 & ", & \\
12 & & \\
\hline
\end{tabular}

Bence Jones protein was not demonstrable by electrophoresis of $300 \times$ concentrated urine but was clearly visible by immunofixation. Two of the latter patients had no demonstrable serum paraprotein. The difficulty of identifying Bence Jones protein by simple electrophoresis in the presence of other proteins is illustrated in the Figure, which also shows how easily the difficulty is overcome by immunofixation. Multiple bands of Bence Jones protein can

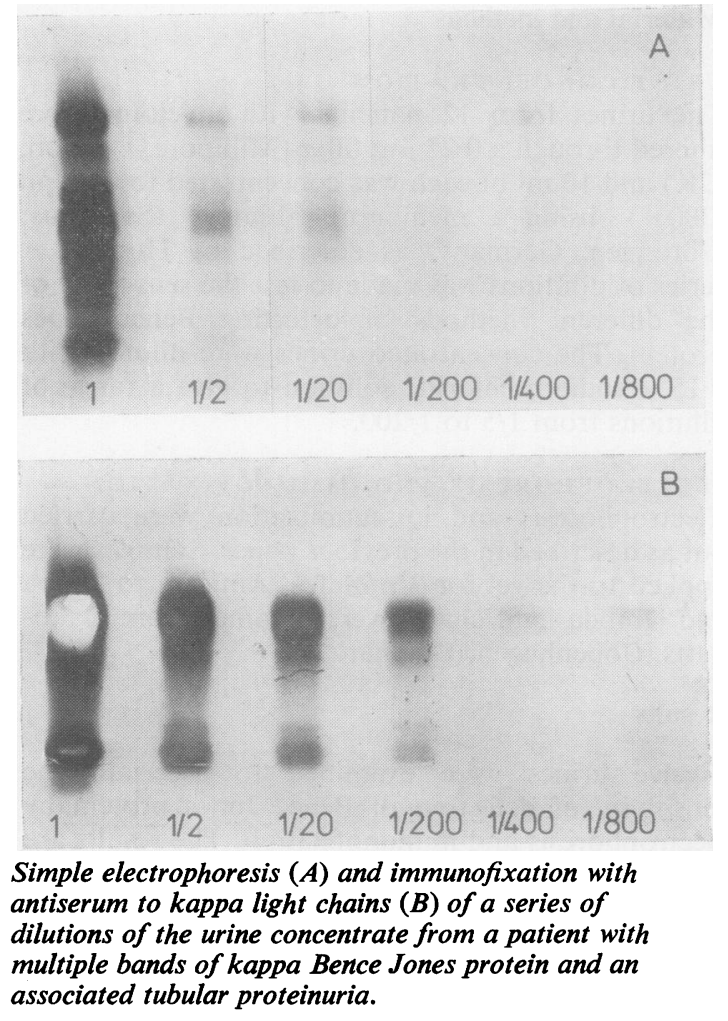

be clearly identified in the presence of a tubular proteinuria.

\section{Discussion}

Existing methods for the detection of Bence Jones protein differ in their sensitivity. The heat test, as described by Bernier and Putnam, ${ }^{3}$ will not detect less than $1.45 \mathrm{~g} / \mathrm{l}^{4}$ and probably misses at least one-third of cases of Bence Jones proteinuria detectable by electrophoresis of urine concentrated $200 \times$ which will detect a concentration of $0.01 \mathrm{~g} / 1$ or slightly lower. The various chemical tests that have been employed also lack sensitivity and specificity, ${ }^{2}$ though Bradshaw's test ${ }^{5}$ is much more sensitive than the heat test and will detect Bence Jones protein in concentration as low as $0.01 \mathrm{~g} / \mathrm{l}$ and will detect about $95 \%$ of cases detectable by electrophoresis. ${ }^{2}$ It is, however, non-specific, detecting polyclonal free light chains and also intact immunoglobulins. Immunoelectrophoresis is potentially more sensitive than electrophoresis but suffers the disadvantage mentioned above. We have found immunofixation to be up to 10 times more sensitive than simple electrophoresis with a detection limit as low as $0.001 \mathrm{~g} / \mathrm{l}$. Its sensitivity is well illustrated by the cases in which Bence Jones proteinuria was detected by immunofixation but not by electrophoresis of the concentrated urine alone. In addition to this increase in sensitivity, immunofixation has the advantage of specificity, namely, Bence Jones proteins are easily recognised even in the presence of tubular proteinuria and considerable heterogeneous free light chain excretion. Large numbers of samples may also be examined at relatively low cost in time and antiserum consumption. We suggest that this technique should replace electrophoresis and immunoelectrophoresis for the routine detection and identification of Bence Jones protein.

\section{References}

${ }^{1}$ Hobbs JR. Immunoglobulins in clinical chemistry. Adv Clin Chem $1971 ; 14: 219-317$.

${ }^{2}$ Hobbs JR. Bence-Jones proteins. Essays Med Biochem 1975;1:105-31.

${ }^{3}$ Bernier GM, Putnam FW. Polymerism, polymorphism, and impurities in Bence-Jones proteins. Biochim Biophys Acta 1964;86:295-308.

${ }^{1}$ Lindström FD, Williams RC, Jr, Swaim WR, Freier EF. Urinary light-chain excretion in myeloma and other disorders - an evaluation of the Bence-Jones test. J Lab Clin Med 1968;71:812-25.

5 Bradshaw TR. The recognition of myelopathic albumin in the urine. $\mathrm{Br}$ Med J 1906;ii:1442-4.

Requests for reprints to: Dr JT Whicher, Department of Chemical Pathology, Bristol Royal Infirmary, Bristol, BS2 8HW, UK. 